ment of Mr. John Evans and Mr. Flower, that the whole district abounds with fragments of flint implements, which shows that the country was occupied at the time when crannoges were constructed.

The President then read the following paper:- "On the Discovery of new Beds of Crag." Much credit was gained by the Norwich Geological Society through the labours of Mr. Taylor in ascertaining the distinction between the fluvio-marine, and the upper marine portion of the Norwich Crag. The position of these crags is beneath the Chillesford clay, which appears above them in the Bramerton section. Since that discovery, the Tellina Balthica Crag has been observed at Belaugh, Coltishall, Wroxham, Horstead, Sherringham, and Weybourne, above the Chillesford Clay, of a more Arctic character, and approaching nearer to the Glacial period, which is evidenced by the Lower Boulder-clay or Till. As this crag will be descrided by Mr. Harmer, Mr. Gunn said he would leave it in his hands, and proceed to mention another bed of crag at Sherringham, which occurs far above the Tellina Balthica bed-it rests on the Upper Boulder-clay. The deposit is 15 feet in thickness, and is composed of sand with shells, which are so abundant as to justify the term "Crag" being applied to it. Most of the shells are in a very fragmentary state, so much so, that only one species could be determined-it is, according to $\mathrm{Mr}$. Searles Wood, a thickened form of Tellina Balthica.-Norwich Mercury, Jan. 16, 1869.

\title{
COREFSPONDFINCE.
}

\section{THE PLEISTOCENE FRESH-WATER DEPOSIT AT HACKNEY DOWNS.}

SIR,-I must again trespass on your valuable space for a few final lines with reference to the above subject. Since my letter appeared in your journal I have seen Mr. Grugeon, and understand that some shells which he gave me early in the year 1866 were collected by Mr. Skertchly; I was not aware of this before. The facts of the case are as follows. I called at Mr. Grugeon's house; a few of the Hackney Down shells were lying there; he told me I could have them, and then gave me to understand that they were collected by his son, but he now tells me they came from Mr. Skertchly. They were of the commoner species, unsorted and unnamed, and it is upon this only that the charge contained in GEOLOGICAI. Magazine, No. 50, is brought against me, and which in effect is, that Mr. Skertchly sent me "a set" of the Hackney Down shells, and that I afterwards published a list of them as my own. I leave your readers to judge how far such an accusation was justified by the facts of the case, and will only add, in conclusion, that the species enumerated in the Geological Repertory were my own collecting, the result of many visits to the spot, and of much time spent at home in examining the sand, etc., with a magnifyer, for the rarer and more minute species.

ISLINGTON, 1868.

George J. Smith.

\section{CORBICULA (CFRENA) FLUMINALIS IN CAPE COLONY.}

Sir,-This species, which is extinct-though very abundant in a fossil state in various parts of Europe-I found living in the Vaal river, in South Africa, in July last. I found it rather abundant about three miles from the junction of the Vaal and Great Orange rivers, about $29^{\circ}$ south latitude. I procured about twenty specimens. The river here is rather rapid, though 
not deep, and runs over a bed of stones, mostly small boulders of Trap, from three to six or eight inches in diameter. Living examples have long been known from the River Nile, and there are also some specimens in the British Museum having the locality of Natal attached to them; but I believe these are the first that have heen found in Cape Colony. Between Natal and Cape Colony are the Drachenberg and other ranges of mountains, yet this species of Cyrena seems to be the same from both localities. I am expecting these specimens in a case which was packed before I left South Africa. In England this species is abundant, though extinct in many of our brick-clays, associated with remains of the Elephant, Rhinoceros, Hippopotamus, etc.; and in South Africa the same genera of animals still exist with this little shell, although during the last twenty years the larger animals are driven further up the country, and but seldom appear in these haunts. About the time, however, that I was in Hope Town two Hippopotami were reported in the Great Orange River near Hope Town, and many persons went out after them, but with no success, although I believe some shots were fired, but the tracks of the animals were visible, and were said to be those of an adult and young animal.-J JMES R. Gregory.

\section{PETROLOGY AND LITHOLOGY.}

SrR.-In the January number of the Quarterly Journal of Science, the reviewer of the progress of Mineralogy during the last quarter says, while noticing new works on Petrology-" Probably it would be difficult to point to any branch of natural science which at the present time occupies a more unsatisfactory position in this country than that science which, according as it is pursued in the field or in the cabinet has been variously designated Petrology or Lithology, in other words, the study of rocks, as distinguished from that of minerals. No one can gainsay the first part of this quotation, as without doubt books in the English language on both Lithology and Petrology, especially the latter, are sadly required, the only work at all approaching to the latter science being Lawrence's translation of Cotta, and any one who has studied it, must see how little the true science of Petrology has been regarded in the compilation of that book. But to return to the quotation-the latter part (now printed in italics) seems to be highly objectional, as in its present form it can scarcely fail to mislead students into imagining that Petrology is simply the study of rocks in any form, while Litbology is the study of minerals; when in reality the former is confined to the study of rocks in mass, and the latter to pieces of rock; by which means a rock may lithologically belong to one class, and petrologically to another. As for instance many of Cotta's quartziferous porphyries are lithologically granites, as they contain quartz, felspar and mica, while petrologically they are Felstones. A geologist divides rocks petrologically or into their natural divisions, and a mineralogist lithologically, as they wish to make a multiplicity of " distinct varieties." The difference between Petrology and Lithology has been fully ex- 